Dept. of Theriogenology,

Fac. of Vet. Medicine, Assiut University, Assiut, Egypt.

\title{
ULTRASONOGRAPHIC EVALUATION FOR THE EFFECT OF POSTPARTAL OVARIAN ACTIVITY AND UTERINE INVOLUTION ON SUBSEQUENT REPRODUCTIVE PERFORMANCE OF DAIRY COWS
}

(With 5 Tables)

\author{
By \\ H. A. HUSSEIN
}

(Received at 16/12/2004)

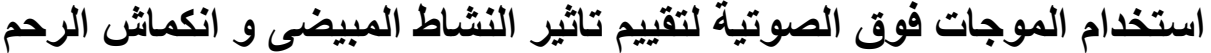

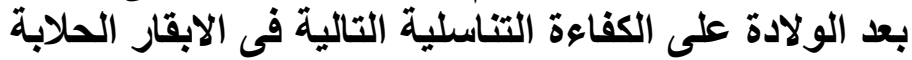

\section{حسن عبل الصبور على حسين}

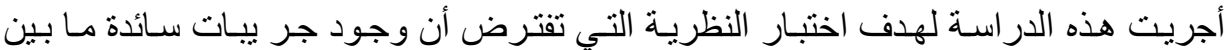

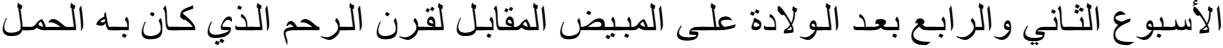

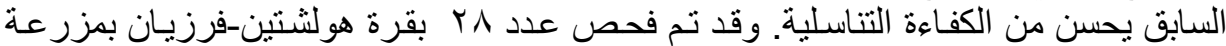

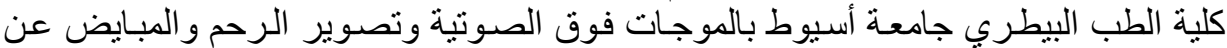

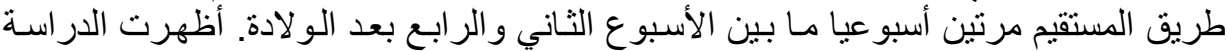

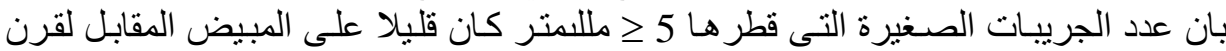

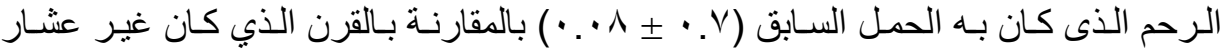
( ع ..

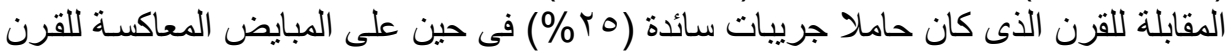

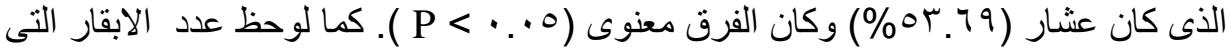

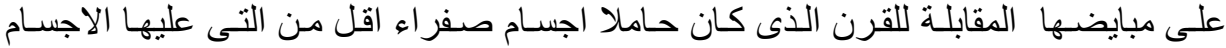

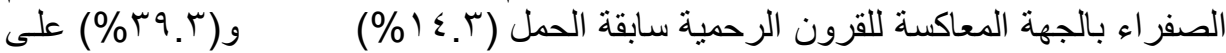

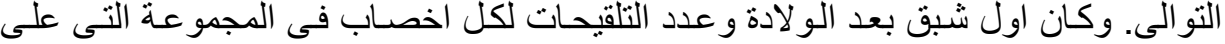

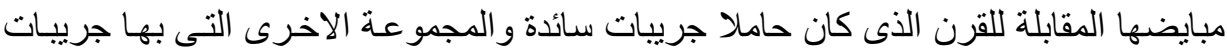

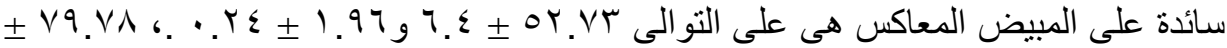

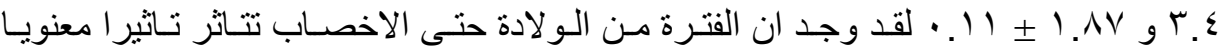

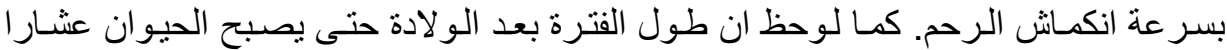

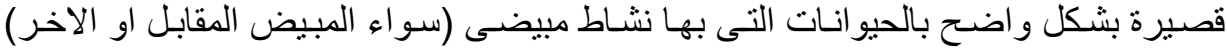

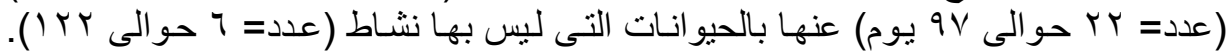
على المبيضين الثاء فترة الفحص وكان الفرق معنويا 
تنشأ سؤال شيق و هو: كيف نؤثر هذة الجريبات على الكفائة التناسلية للحيوان؟ هل لها تاثير

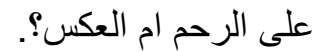

\section{SUMMARY}

The objective of this study was to test the hypothesis that presence of dominant follicle in the ovary ipsilateral to the previously gravid uterine horn (PGH), between 2 and 4 weeks postpartum, improves subsequent reproductive performance. A total 28 Holstein-Fresian lactating cows in the farm of the Faculty of veterinary medicine Assiut university were examined using transrectal ultrasonography twice weekly between second and fourth week postpartum. The number of follicles ( $\geq 5 \mathrm{~mm}$ diameter) in the ovary ipsilateral to the PGH was fewer than that in the ovary contralateral to the PGH $(0.70 \pm 0.08$ vs. $1.04 \pm 0.09, \mathrm{P}<0.001)$. There were fewer cows with a dominant follicle $(\geq 10 \mathrm{~mm}$ diameter $)$ in the ovary ipsilateral to the PGH compared with those with dominant follicles in the contralateral ovary $(25.0 \%, \mathrm{n}=7$, vs. $53.69 \%, \mathrm{n}=15, \mathrm{P}$ $<0.05)$. In addition, there were fewer cows with a corpus luteum in the ovary ipsilateral to the PGH compared with those having corpora lutea in the contralateral ovary $(4 / 28,14.3 \%)$ vs. $(11 / 28,39.3 \%, \mathrm{P}<0.001)$. Days to the $1^{\text {st }}$ service and number of service per conception in the group which had dominant follicles in the ovary ipsilateral to the PGH $(n=7)$ and animals without such follicles $(n=21)$ were $52.73 \pm 6.4,1.97 \pm 0.24$ and $79.78 \pm 3.4,1.87 \pm 0.11$ respectively. Days open in the animals with ovarian activity in either ovaries $(n=22)$ were $97.04 \pm 8.4$ days and in animals without ovarian activity $(\mathrm{n}=6)$ were $122.2 \pm 7.8$ days $(\mathrm{P}<0.01)$. The calving to conception interval was shorter in those animals with a smaller diameter of the $\mathrm{PGH}(<60 \mathrm{~mm}$ diameter was $95.8 \pm 5.3$ days and $>60 \mathrm{~mm}$ diameter was 122. $3 \pm 1.09$ days, $\mathrm{P}<0.01)$. This observation raises an interesting question: How does this follicle affect subsequent fertility - does the follicle exert a local influence on the uterus, or vice versa?.

Key words: Cow, ultrasonography, postpartum, ovarian activity, uterine involution, fertility. 


\section{INTRODUCTION}

An excessively long postpartum estrus interval results in huge economic losses, as well as increasing managerial problems. The relationship between reproductive performance and postpartum changes in the uterus or ovaries of cattle has been investigated by a number of authors (Studer and Morrow, 1978, Oltenacu et. al, 1983). However, little attention has been paid to the local relationship between the previously gravid uterine horn $(\mathrm{PGH})$ and follicular growth in the ipsilateral ovary.

Previous results suggested that the occurrence of a large follicle, determined by palpation per rectum, in the ovary ipsilateral to the PGH on day $26 \pm 3$ postpartum, increased the likelihood of shorter calving to conception intervals (Bonnet et. al, 1993). However the accuracy of manual palpation in accurately identifying and measuring such structures, as well as determining the degree of uterine involution, is open to criticism due to the high level of subjectivity. The monitoring of follicular growth and uterine involution in cows can be improved by the use of transrectal ultrasonography (Pierson and Ginther, 1988, Savio et. al, 1990).

Greatest follicular activity after calving occurs initially in the ovary contralateral to the PGH (Lewis et al., 1984, Guilbault et al., 1987, Risco et al., 1994). Kamimura et al. (1993) reported that only $18 \%$ of the first dominant follicles were identified in the ovary ipsilateral to the PGH. The negative influence of the previously gravid horn on the return of ovarian cyclicity in the ovary ipsilateral to the PGH declines with increasing time postpartum (Saiduddin et al., 1967, Foote and Peterson 1968, Marion and Gier, 1968).

There are conflicting reports on the relationship between the return of ovarian cyclicity (as determined by the interval from calving to first rise in milk progesterone concentration) and calving to conception interval. Darwash et al. (1997) claimed that early return of cyclicity is associated with shorter calving to conception interval, whereas Smith and Wallace (1998) claimed the reverse. However, such studies are unable to determine in which ovary the return to cyclicity occurs in relation to the $\mathrm{PGH}$.

The objective of this study was to evaluate the hypothesis that presence of large follicle ( $\geq 10 \mathrm{~mm}$ diameter) follicle in the ovary ipsilateral to the PGH, between 2 and 4 weeks postpartum, improves subsequent reproductive performance. 


\section{MATERIALS and METHODS}

A total of 28 Holstein-Friesian clinically healthy dairy cows were included in this study. The cows were between 4 and 9 years old belonged to the farm of the Faculty of Veterinary Medicine, Assiut University. During the study, the animals were housed in fixed stall barns with grass green food (Trifolium alexandrinum) available ad libitum. Concentrate feed was supplied at $0.3 \mathrm{~kg} / \mathrm{L}$ milk yield. The farm had policy of natural mating beginning from 45 days postpartum. All animals were hand bred at first post partum observed estrus by fertile bull.

The cows were examined twice per week beginning from second week postpartum to the fourth week. Calving date, date of examination and lactation number were recorded.

The PGH was determined transrectally as that which was longer and of greater diameter than the contralateral horn. The genital tract was scanned per rectum using ultrasound scanner with $6 / 8 \mathrm{MHz}$ linear array transrectal probe (PIE MEDICAL 100 L. C., Holland) twice weekly for three weeks. Follicles were defined as nonechogenic (black) spherical structures with a clear demarcation between the follicular wall and the rest of the ovarian matrix. Corpora lutea were defined as grainy echogenic structures that had a well-defined border with the less echogenic ovarian stroma. The internal diameter of the largest follicular and luteal ovarian structures and the external diameter of the uterine horns at mid-point were measured using the internal calipers of the machine. When the image of the scanned structure was not spherical, the diameter was estimated by averaging two $90^{\circ}$ measurments. In addition, follicles $>5 \mathrm{~mm}$ diameter in each ovary were counted. Sonograms were recorded and printed by Sony video graphic printer (UP-890 MD, Australia).

Ovarian activity was defined as the presence of a follicle and/ or corpus luteum $\geq 10 \mathrm{~mm}$ diameter. Similar definitions have been used previously (Guilbault et al., 1987, Risco et al., 1994).

The data were analyzed for 2 periods of calving to examination (14 to 21 and 22 to 28 days). Results are expressed as mean \pm SEM. Analysis performed using SPSS (Version 8.0, SPSS, Chicago, IL). P values of $<0.05$ were regarded as significant. 


\section{RESULTS}

Follicles $\geq 5 \mathrm{~mm}$ diameter were observed in both ovaries ipsilateral and contralateral to the PGH. The number of follicles $\geq 5 \mathrm{~mm}$ diameter in the ovary ipsilateral to the PGH was fewer than that in the ovary contralateral to the PGH $(0.70 \pm 0.08$ vs. $1.04 \pm 0.09, \mathrm{P}<0.001)$ (Table 1). The difference in their numbers declined with increasing time from calving to examination (Table 1). There were significant correlation between the interval from calving to examination and the number of follicles $\geq 5 \mathrm{~mm}$ diameter $(\mathrm{r}=0.14, \mathrm{P}<0.05)$ in the ovary ipsilateral to the PGH.

Fewer cows had a CL in the ovary ipsilateral to the PGH compared with the contralateral ovary (Table $2, \mathrm{P}<0.001$ ). In addition, the cows had a follicle $\geq 10 \mathrm{~mm}$ diameter in the ovary ipsilateral to the PGH were fewer compared with those which had follicle in the contralateral ovary (Table $2, \mathrm{P}<0.001$ ). In some corpora lutea there was a normal non echogenic lacuna (corpora lutea with cavities).

The proportion of cows with a follicle $\geq 10 \mathrm{~mm}$ diameter differed between the ovaries ipsilateral and contralateral to the PGH at 14 to 21 and 22 to 28 days from calving to examination (Table 2). There were significant correlation between the interval from calving to examination and the presence of cows possessing follicle $\geq 10 \mathrm{~mm}(\mathrm{r}=0.13, \mathrm{P}<$ $0.05)$ in the ovary ipsilateral to the PGH.

The calving to $1^{\text {st }}$ postpartum estrus interval was $52.73 \pm 6.4$ days in the first group which had dominant follicles in the ovary ipsilateral to the PGH $(n=7)$, while in the second group, the animals without such follicles $(\mathrm{n}=21)$, was $91.31 \pm 5.3$ days the difference was significant $(\mathrm{P}<0.01)$. The number of service per conception was $1.97 \pm$ 0.24 in first group against $1.87 \pm 0.11$ in the second group, the difference was not significant (Table 3).

The calving to conception interval was shorter in those animals with a smaller diameter of the PGH $(\mathrm{P}<0.01)$ (Table, 4).

Days open in the animals with ovarian activity in either ovaries at 2 periods after calving $(n=22)$ were $97.04 \pm 8.4$ days and in the animals without ovarian activity $(n=6)$ were $122.2 \pm 7.8$ days and the difference was significant $(\mathrm{P}<0.01)$ (Table, 5). 
Table 1: The number of follicles $\geq 5 \mathrm{~mm}$ diameter in the ovary ipsilateral or contralateral to the previously gravid uterine horn at 2 time periods after calving

\begin{tabular}{|l|c|c|c|}
\hline \multirow{2}{*}{$\begin{array}{l}\text { Calving to examination } \\
\text { period (days) }\end{array}$} & \multirow{2}{*}{$\begin{array}{c}\text { Number } \\
\text { of cows }\end{array}$} & \multicolumn{2}{|c|}{$\begin{array}{c}\text { number of follicles } \\
\text { (mean } \pm \text { SEM) }\end{array}$} \\
\cline { 2 - 4 } 14 to 21 & 12 & $\begin{array}{c}0.56 \pm 0.08^{\mathrm{ab}} \\
(0-2)\end{array}$ & $\begin{array}{c}0.97 \pm 0.09^{\mathrm{ab}} \\
(0-3)\end{array}$ \\
\hline 22 to 28 & 16 & $\begin{array}{c}0.84 \pm 0.07^{\mathrm{a}} \\
(0-3)\end{array}$ & $\begin{array}{c}1.09 \pm 0.08^{\mathrm{a}} \\
(0-4)\end{array}$ \\
\hline Total & 28 & $\begin{array}{c}0.70 \pm 0.08^{\mathrm{ab}} \\
(0-3)\end{array}$ & $\begin{array}{c}1.04 \pm 0.09^{\mathrm{ab}} \\
(0-4)\end{array}$ \\
\hline
\end{tabular}

Values are significantly different between the ipsilateral and contralateral ovary within a calving to examination period

$\left({ }^{\mathrm{ab}} \mathrm{P}<0.001,{ }^{\mathrm{a}} \mathrm{P}<0.01\right)$.

Table 2: Percent of animals possessing follicles $\geq 10 \mathrm{~mm}$ diameter and $\mathrm{CL}$ in the ovary ipsilateral or contralateral to the previously gravid uterine horn at 2 time periods after calving.

\begin{tabular}{|c|c|c|c|c|c|}
\hline \multirow{2}{*}{$\begin{array}{l}\text { Calving to examination } \\
\text { period (days) }\end{array}$} & \multirow{2}{*}{$\begin{array}{l}\text { Number } \\
\text { of cows }\end{array}$} & \multicolumn{2}{|l|}{ Ipsilateral ovary } & \multicolumn{2}{|l|}{ Contralateral ovary } \\
\hline & & $\begin{array}{l}\% \text { of cows } \\
\text { having follicles } \\
\geq 10 \mathrm{~mm}\end{array}$ & $\begin{array}{l}\% \text { of cows } \\
\text { having } \mathrm{CL}\end{array}$ & $\begin{array}{l}\% \text { of cows } \\
\text { having follicles } \\
\geq 10 \mathrm{~mm}\end{array}$ & $\begin{array}{l}\% \text { of cows } \\
\text { having CL }\end{array}$ \\
\hline 14 to 21 & 12 & $16.7^{\mathrm{abc}}$ & 33.3 & $75.0^{\mathrm{abc}}$ & 33.3 \\
\hline 22 to 28 & 16 & $31.3^{\mathrm{ab}}$ & $18.8^{\mathrm{ab}}$ & $43.8^{\mathrm{ab}}$ & $43.8^{\mathrm{ab}}$ \\
\hline Total & 28 & $25.0^{\mathrm{abc}}$ & $25.0^{\mathrm{abc}}$ & $53.6^{\mathrm{abc}}$ & $39.3^{\mathrm{abc}}$ \\
\hline
\end{tabular}

Values are significantly different between the ipsilateral and contralateral ovary within calving to examination period

$\left({ }^{\mathrm{abc}} \mathrm{P}<0.001,{ }^{\mathrm{ab}} \mathrm{P}<0.01\right)$. 
Table 3: The calving to $1^{\text {st }}$ postpartum estrus interval (days) and number of service per conception In cows with or without dominant follicles in the ovary ipsilateral to the PGH

\begin{tabular}{|l|c|c|}
\hline Criteria & $\begin{array}{c}\text { Cows with dominant follicles } \\
(\mathrm{n}=7)\end{array}$ & $\begin{array}{c}\text { Cows without dominant follicles } \\
(\mathrm{n}=21)\end{array}$ \\
\hline $\begin{array}{l}\text { Calving to } 1^{\text {st }} \text { postpartum } \\
\text { estrus interval (days) }\end{array}$ & $\begin{array}{c}52.73 \pm 6.4^{\mathrm{ab}} \\
(22-79)\end{array}$ & $\begin{array}{c}91.31 \pm 5.3^{\mathrm{ab}} \\
(55-119)\end{array}$ \\
\hline $\begin{array}{l}\text { Number of service per } \\
\text { conception }\end{array}$ & $\begin{array}{c}1.97 \pm 0.24 \\
(1-3)\end{array}$ & $\begin{array}{c}1.87 \pm 0.11 \\
(1-3)\end{array}$ \\
\hline
\end{tabular}

Values are significantly different between the cows with and without dominant follicle in the ovary ipsilateral to the PGH $\left({ }^{\mathrm{ab}} \mathrm{P}<0.01\right)$. values without small letters are not significantly differ.

Table 4: The calving to conception interval in relation to the previously gravid uterine horn $(\mathrm{PGH})$ diameter at 28 day after calving.

\begin{tabular}{|l|c|c|}
\hline $\begin{array}{l}\text { Diameter of the PGH at 28 day } \\
\text { p.p (mm). }\end{array}$ & $\begin{array}{c}\text { Number } \\
\text { of cows }\end{array}$ & Calving to conception interval \\
\hline$<60 \mathrm{~mm}$ diameter & 18 & $95.8 \pm 5.3^{\mathrm{a}}$ \\
& $(42-115)$ \\
$>60 \mathrm{~mm}$ diameter & 10 & $122.3 \pm 1.09^{\mathrm{a}}$ \\
& & $(75-165)$ \\
\hline
\end{tabular}

Values are significantly different between the PGH diameter $<60 \mathrm{~mm}$ and $>60 \mathrm{~mm}$ diameter $\left({ }^{\mathrm{a}} \mathrm{P}<0.01\right)$.

Table 5: Days open in animals with or without ovarian activity in either ovaries at 2 periods after calving

\begin{tabular}{|l|l|c|c|}
\hline \multirow{2}{*}{$\begin{array}{l}\text { Calving to } \\
\text { examination } \\
\text { period } \\
\text { (days) }\end{array}$} & \multirow{2}{*}{$\begin{array}{l}\text { Number } \\
\text { of cows }\end{array}$} & \multicolumn{2}{|c|}{ Days open (days) } \\
\cline { 3 - 4 } & & $\begin{array}{c}\text { With ovarian activity } \\
\text { (n) }\end{array}$ & $\begin{array}{c}\text { Without ovarian activity } \\
\text { (n) }\end{array}$ \\
\hline 14 to 21 & 12 & $\begin{array}{c}100.5 \pm 10.0^{\text {ab }} \\
(9)\end{array}$ & $\begin{array}{c}146.7 \pm 11.9^{\text {ab }} \\
(3)\end{array}$ \\
\hline 22 to 28 & 16 & $\begin{array}{c}93.58 \pm 7.0 \\
(13)\end{array}$ & $\begin{array}{c}96.8 \pm 5.9 \\
(3)\end{array}$ \\
\hline Total & 28 & $97.04 \pm 8.4^{\mathrm{a}}$ & $122.2 \pm 7.8^{\mathrm{a}}$ \\
& & $(22)$ & $(6)$ \\
\hline
\end{tabular}

Values are significantly different between cows with and without ovarian activity $\left({ }^{\mathrm{ab}} \mathrm{P}<0.01,{ }^{\mathrm{a}} \mathrm{P}<0.05\right)$, values without small letters are not significantly differ. 


\section{DISCUSSION}

The results of the present study showed that the presence of a follicle $\geq 10 \mathrm{~mm}$ diameter between 14 and 28 days after calving in the ovary ipsilateral to the $\mathrm{PGH}$ is associated with shorter calving to conception intervals.

This observation confirmed the study of Bonnet et al. (1993) on 66 cows by. They reported that cows with good subsequent reproductive performance had larger follicular diameter $(6.1 \pm 1.3 \mathrm{~mm})$ on the ovary ipsilateral to the $\mathrm{PGH}$, compared with a smaller follicle $(2.7 \pm 0.9 \mathrm{~mm})$ in cows with poor performance. The shorter calving to conception interval associated with the presence of a larger follicle in the ovary ipsilateral to the PGH may be due to the influence of the follicle on the uterine endometrium and/ or myometrium. One hypothesis is that estradiol synthesiyed by a follicle $\geq 10 \mathrm{~mm}$ diameter has a benifical local effect on uterine function. Plasma estradiol concentrations are greater within the utero-ovarian vien draining the ovary containing the ovulatory follicle (Ireland et al., 1984).

The current study shows that cows with ovarian activity, as defined by ultrasonographic presence of a CL and/ or follicle $\geq 10 \mathrm{~mm}$ diameter, had a shorter calving to conception interval compared with those lacking these structures. This observation supports Shanks et al. (1979), who reported shorter calving to conception intervals for cows that had an initial ovulation before, rather than after 41 days postpartum. Similarly, Darwash et al. (1997) reported a significant reduction in the calving to conception interval with shorter intervals to the first postpartum increase in milk progesterone concentration, although, Smith and Wallace (1998) observed the reverse.

A local effect of the uterus on ovarian function is an established concept, for example, in relation to the transfer of luteolysins (Ginther, 1968), and it has been implicated in the action of interferon (Spencer et al., 1999). Furthermore, in the present study there was a positive correlation between postpartum interval and number of follicles in the ovary ipsilateral to the PGH. These observations would support a hypothesis of a declining influence of uterine-drived inhibitor on ovarian function as uterine involution progresses. Possible uterine factors could include inflammatory mediators such as PGF2 $\alpha$, which is produced by postpartum uterus in high concentrations during involution and in response to utereine infection (Lindell et al., 1982). However, there are a large number of other inflammatory mediators, particularly cytokines, 
that participate in folliculogenesis and ovulation (Terranova and Rice, 1997).

An alternative mechanism might be via immune or inflammatory cell cytokine release and/ or cell-cell communication in the ovary. Neutrophils readly migrate into the uterine lumen in response to a chemotactic stimulus at all stages of bovine reproductive cycle. Furthermonre, intrauterine and peripheral neutrophils function is modified by reproductive hormonal status, retained fetal membrane and uterine infection (Cai et al., 1994, Subandrio and Noakes, 1997). Perhaps immune cells could migrate from the uterine horn, or a uterinederived chemotactic substance could attract immune cells to the ipsilateral ovary, and so influene folliculogenesis. Immune cells have been detected in ovarian follicles and luteal tissue in association with a modulation of follicular and luteal activity (Brannstrom et al., 1994, Gaytan et al., 1998, Penny et al. 1999).

In this study it was found that, follicular activity was suppressed in the ovary ipsilateral to the PGH between 14 and 28 days postpartum. The presence of a follicle $\geq 10 \mathrm{~mm}$ diameter in the ovary ipsilateral to the PGH between 14 and 28 days postpartum was associated with shorter calving to conception intervals. It was concluded that, presence of dominant follicle in the ovary ipsilateral to the previously gravid uterine horn (PGH), between 2 and 4 weeks postpartum as well as rapid uterine involution, improve subsequent reproductive performance.

\section{REFERENCES}

Bonnet, B.N.; Martin, S.W. and Meek, A.H. (1993): Associations of clinical findings, bacteriological and histological results of endometrial biopsy with reproductive performance of postpartum dairy cows. Prev. Vet. Med., 15: 205-220.

Brannstrom, M.; Pascoe, V.; Norman, R.J. and McClure, N. (1994):

Localization of leukocyte subsets in the follicle wall and in the corpus luteum throughout the human menstrual cycle. Fertl Steril, 61: 488-495.

Cai, T.Q.; Weston, P.G.; Lund, L.A.; Brodir, B.; McKenna, D.J. and Wagner, W.C. (1994): Association between neutrophil functions and periparturient disorders in cows. Am. J. Vet. Res., 55: 934-943. 
Darwash, A.O.; Lamming, G.E. and Woolliams, J.A. (1997): The phenotypic association between the interval to post-partum ovulation and traditional measures of fertility in dairy cattle. Anim. Sci., 65: 9-16.

Foote, W.D. and Peterson, D.W. (1968): Relatioships between side of pregnancy and side of subsequent ovarian activities in beef and dairy cattle. J. Reprod Fertil, 16: 415-421.

Gaytan, F.; Moales, C.; Bellido, C.; Aguilar, E. and Sanchey-Criado, J.E. (1998): Ovarian follicle macrophages: is follicular atresia in the immature rat a macrophage-mediated event? Biol Reprod, 58: 52-59.

Ginther, O. (1968): Utero-ovarian relationships in cattle:physiologic aspects. JAVMA, 153: 1656-1664.

Guilbault, L.A.; Thatcher, W.W.; Drost, M. and Haibel, G.K. (1987): Influence of a physiological infusion of Prosraglandin-F2-alpha into postpartum cows with partially suppressed endogenous production of prostaglandins. 1.Uterine and ovarian morphological responses. Theriogenology, 27: 931-946.

Ireland, J.J.; Fogwell, R.L.; Oxender, W.D.; Ames, K. and Cowley, J.L. (1984): Production of estradiol by each ovary during the estrus cycle of cows. J. Anim. Sci., 59: 764-771.

Kamimura, S.; Ohgi, T.; Takahashi, M. and Tsukamoto, T. (1993): Postpartum resumption of ovarian activity and uterine involution monitored by ultrasonography in Holstein cows. J. Vet. Med. Sci., 55: 643-647.

Lewis, G.S.; Thatcher, W.W.; Bliss, E.L.; Drost, M. and Collier, R.J. (1984): Effect of heat stress during pregnancy on postpartum reproductive changes in Holstein cows. J. Anim. Sci., 58: 174186.

Lindell, J-O.; Kindahl, H.; Jansson, L. and Edqvist, L-E. (1982) Postpartum release of prostaglandin F $2 \alpha$ and uterine involution in the cow. Theriogenology, 17: 237-243.

Marion, G.B. and Gier, H.T. (1968): Factors affecting bovine ovarian activity after parturition. J. Anim. Sci., 27: 1621-1626.

Oltenacu, P.A.; Britt, J.H.; Braun, R.K. and Mellenberger, R.W. (1983): Relationships among type of parturition, type of discharge from genital tract, involution of cervix and subsequent reproductive performance in Holstein cows. J. Dairy Sci., 66: 612-619. 
Penny, L.A.; Armstrong, D.; Bramley, T.A.; Webb, R.; Collins, R.A. and Watson, E.D. (1999): Immune cells and cytokine production in the bovine corpus luteum throughout the estrus cycle and after induced luteolysis. J. Reprod. Fertil., 115: 96-97.

Pierson, R.A. and Ginther, O.J. (1988): Ultrasonic imaging of the ovaries and uterus in cattle. Theriogenology, 29: 21-37.

Risco, C.A.; Drost, M.; Thatcher, W.W.; Savio, J. and Thatcher, M.J. (1994): Effects of calving related disorders on prostaglandin, calcium, ovarian activity and uterine involution in postpartum dairy cows. Theriogenology:, 42: 183-203.

Saiduddin, S.; Riesen, J.W.; Tyler, W.J. and Casina, L.E. (1967): Some carry-over effects of pregnancy on postpartum ovarian function in the cow cows. J. Dairy Sci., 50: 1846-1847.

Savio, J.D.; Boland, M.P.; Hynes, N. and Roche, J.F. (1990): Resumption of folicular activity in the early post partum period of dairy cows. J. Reprod Fertil, 88: 569-579.

Shanks, R.D.; Freeman, A.E. and Berger, P.J. (1979): Relationship of reproductive factors with interval and rate of conception. J. Dairy Sci., 62: 74-84.

Smith, M.C. and Wallace, J.M. (1998): Influence of postpartum ovulation on re-establishment of pregnancy in multiparous and primiparous dairy cattle. Reprod Fertil Dev., 10: 207-216.

Spencer, T.E.; Stagg, A.G.; OTT, T.L.; Johanson, G.A.; Ramsey, W.S. and Bazer, P.W. (1999): Differential effects of intrauterine and subcutaneous administration of recombinant ovine interferon tau on the endometrium of cyclic ewes. Biol. Reprod, 61: 46470 .

Studer, E. and Morrow, D.A. (1978): Postpartum evaluation of bovine reproductive potential: comparison of findings from genital tract examination per rectum, uterine culture and endometrial biopsy. JAVMA, 172: 489-494.

Subandrio, A.L. and Noakes, D.E. (1997): Neutrophil migration into the uterine lumen of the cow: the influence of endogenous and exogenous sex steroid hormones using two intrauterine chemoattractants. Theriogenology, 47: 824/835.

Terranova, P.F. and Rice, V.M. (1997): Review: Cytokine involvement in ovarian processes. Am. J. Reprod Immunol, 37: 50-63. 
Assiut Vet. Med. J. Vol. 51 No. 104 January 2005 